\title{
Geochemical Consideration of some Granitoids around Ojirami-Ogbo and Environs, Southwestern Nigeria
}

\author{
*1ODOKUMA-ALONGE, O; ${ }^{2}$ EGWUATU, PN; ${ }^{3}$ OKUNUWADJE, SE
}

\author{
Department of Geology, Faculty of Physical Sciences, University of Benin, Benin City, Nigeria \\ *Corresponding Author Email: ovie.odokuma-alonge@uniben.edu
}

\begin{abstract}
Five (5) granitoid samples from Ojirami-Ogbo and Environs in Akoko-Edo area of southwestern Nigeria were obtained with the aim of determining their geochemical properties using the XRF and Xrd techniques. Results from the analysis revealed the presence of $\mathrm{SiO}_{2}(51.41-64.84 \%), \mathrm{Al}_{2} \mathrm{O}_{3}(21.37-36.25 \%), \mathrm{Fe}_{2} \mathrm{O}_{3}(5.89-8.02 \%), \mathrm{MgO}$ $(0.98-2.11 \%), \mathrm{K}_{2} \mathrm{O}(0.02-0.97 \%)$ and $\mathrm{Na}_{2} \mathrm{O}(0.04-0.08 \%)$ all in wt\%. Using the $\mathrm{Al}_{2} \mathrm{O}_{3}$ and $\mathrm{SiO}_{2}$ saturation schemes in classifying igneous rocks, sample two, three, four and five gave $\mathrm{Al}_{2} \mathrm{O}_{3}$ wt $\%$ values of $33.30 \%, 32.00 \%, 23.20 \%, 21.37 \%$ greater than the molars proportions of $\left(\mathrm{Al}_{2} \mathrm{O}_{3} / \mathrm{CaO}+\mathrm{Na}_{2} \mathrm{O}+\mathrm{K}_{2} \mathrm{O}\right)$ with values 22.54, 30.06, 22.10 and 14.07, and are peraluminous rocks while sample one had $36.25 \%$ and 43.10 , respectively and is considered to be metaluminous. The $\mathrm{SiO}_{2}$ composition of the rocks ranges from $51.41-66.40 \%$ hence reveals a mafic to intermediate composition. The main felsic minerals from $\mathrm{XrD}$ analysis revealed the presence of quartz, alkali and plagioclase feldspars. Using the QAP diagram, the rocks fall within the granitoidal class.
\end{abstract}

\section{DOI: https://dx.doi.org/10.4314/jasem.v23i6.20}

Copyright: Copyright (C) 2019 Odokuma-Alonge et al. This is an open access article distributed under the Creative Commons Attribution License (CCL), which permits unrestricted use, distribution, and reproduction in any medium, provided the original work is properly cited.

Dates: Received: 22 April 2019; Revised: 30 May 2019; Accepted 19 June 2019

Key words: geochemical, silica-saturation, alumina-saturation, major oxides

Granite is a felsic intrusive igneous rock that is granular and phaneritic in texture. Granite can be predominantly white, pink, or gray in colour, this is dependent on the mineralogy. Granite is an igneous rock with at least $20 \%$ quartz and up to $65 \%$ alkali feldspar by volume. Granitic is a term meaning granite-like and is applied to granite and a group of intrusive igneous rocks with similar textures and slight variations in composition and origin. These rocks consist of feldspar, quartz mica, and amphibole minerals which form an interlocking, somewhat equigranular matrix of feldspar and quartz with scattered darker biotite mica and amphibole (often hornblende) peppering the lighter colored minerals. Occasionally, some individual crystals (phenocryst) are larger than the groundmass, in which case the texture is known as porphyritic (Rahaman, 1988; Odeyemi, 1988). Petrographic examination is required for identification of specific types of granitoids. Granite differs from granodiorite in that at least $35 \%$ of the feldspar in granite is alkali feldspar as opposed to plagioclase. It is the potassium feldspar that gives granite a distinctive pink color. Granite is nearly always massive (lacking any internal structure), hard and tough, therefore it has gained widespread use in human history, and more recently as a construction material. The average density of granite is between 2.65 and $2.75 \mathrm{~g} / \mathrm{cm}^{3}$, its compressive strength usually lie above
$200 \mathrm{MPa}$, and its viscosity near STP is $3-6.10^{\wedge} 19 \mathrm{~Pa}$. The melting temperature of dry granite at ambient pressure is $1215-1260^{\circ} \mathrm{C}\left(2219-2300^{\circ} \mathrm{F}\right)$. It is the strongly reduced in the presence of water down to $650^{\circ} \mathrm{C}$ at a few kbars. Granite has poor primary permeability, but strong secondary permeability. Outcrops of granite tend to form tors and massifs. Granites sometimes occur in circular depressions surrounded by a range of hills, formed by the metamorphic aureoles or hornfels. Granite is usually found in the continental plates of the earth crust. Granite is currently known to exist only on earth, where it forms a major part of the continental crust. Granite often occurs as relatively small to less than $100 \mathrm{~km}^{2}$ (stocks) and greater than $100 \mathrm{Km}^{2}$ (batholiths) that are often associated with orogenic mountain ranges. Small dykes of granitic composition called aplites are often associated with margins of granitic intrusions (McCurry, 1971; 1976). In some locations very coarse grained pegmatite masses occur and are granitic in composition. Granitic in composition rocks have been intruded into the crust of the earth during all geologic periods, although quite a number are of Pan African age. A number of authors have classified the basement complex rocks into three or four parts with igneous rocks occurring as a major intrusive phase (Rahaman, 1976; 1988; Oyawoye, 1972; Odeyemi, 1976; 1988; Ajibade and Fitches, 1988). Granitic

*Corresponding Author Email: ovie.odokuma-alonge@uniben.edu 
rocks are widely distributed throughout the continental crust and are the most abundant basement rock that underlies the relatively thin sedimentary veneer of the continents. The aim of this paper, therefore, is to determine the chemical and mineralogical composition of the rocks, hence, classify the rock. The study area is located within latitude $7^{\circ} 18^{\prime} 40^{\prime \prime} \mathrm{N}$ to $7^{\circ} 21^{\prime} 00^{\prime \prime} \mathrm{N}$ and longitude $6^{\circ} 07^{\prime} 30^{\prime \prime} \mathrm{E}$ to $6^{\circ} 14^{\prime} 00^{\prime \prime} \mathrm{E}$ on Auchi Sheet 266 on a scale of 1:100,000 (Figure 1). The study area forms part of the Pan African rocks (charnockites and granitoids) which intrude both the Younger metasedimentary rocks (quartz mica schists, metaconglomerates, psammites, calc gneisses and marbles) and the Older metasedimentary sequences (migmatite gneisses, marbles, quartzites) (McCurry, 1976; Odeyemi, 1976; Rahaman, 1976;1988). The geological map of the study area is shown in Figure 2. The granitic rocks at Ojirami-Ogbo occur as batholiths and are exposed over a wide area. The rocks are porphyritic with the k-feldspar ocurring as phenocrysts in a ground matrix of quartz, biotite, plagioclase, alkali feldspar, hornblende and other mafic minerals. The k-feldspars give the rock its pinkish coloration, while the quartz in the matrix occurs as ribbons. The granites have a massive structure, but some mica in some parts of the rocks possesses a kind of discontinuous alignment.

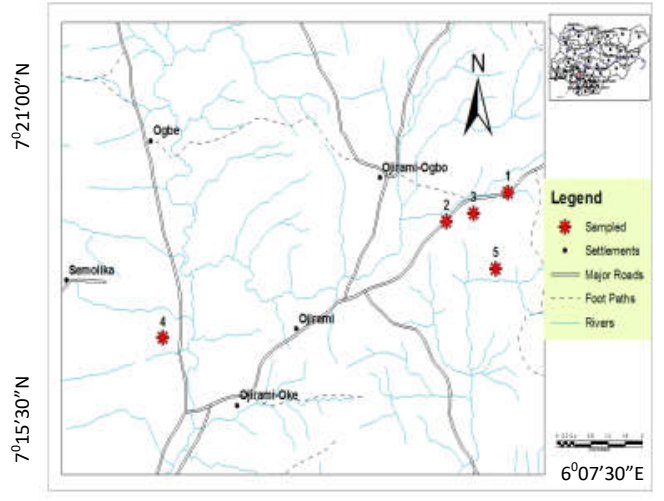

Fig 1: Location map of the samplede $6^{0} \mathrm{p}^{\prime} 8 \Theta^{\prime \prime} \mathrm{In}_{\mathrm{i}}$.

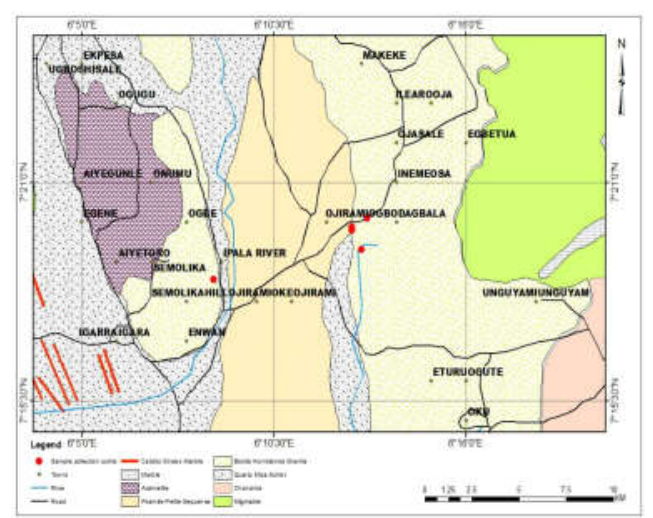

Fig 2: The geological map of the study area

\section{MATERIALS AND METHODS}

Sample collection: Five (5) samples were obtained from some igneous bodies around Ojirami-Ogbo and Semolika. Fresh samples were collected with the aid of a sledge hammer. The samples, well-labeled, were sent to the laboratory at National Steel Raw Materials Exploration Agency, (NSRMEA), Kaduna. The coordinates were determined using a Global Positioning System (G.P.S). The samples were subjected to chemical and mineralogical analysis using the XrF (X-ray Flourescence- MODEL 1200 ARL ADVANT'X THERMOSCIENTIFICS) and Xray Diffractometer $(\mathrm{XrD})$.

Sample preparation and analysis: For the $\mathrm{XrF}$ technique, each sample was crushed with an electric crusher and then pulverized for 60seconds using Herzog Gyro-mill (Simatic, C7-621). Pellets were prepared from the pulverized sample, first by grinding $20 \mathrm{~g}$ of each sample with $0.4 \mathrm{~g}$ of stearic acid for 60 seconds. After grinding, the Gyro mill was cleansed to avoid contamination. One gramme (1g) of stearic acid was weighed into an aluminum cup to act as a binding agent and the cup was subsequently filled with the sample to the level point. The cup was then taken to Herzog pelletizing equipment where it was passed at a pressure of $200 \mathrm{KN}$ for 60 seconds. The $2 \mathrm{mmn}$ pellets were added into a sample holder of the equipment for analysis. For $\mathrm{XrD}$ technique, the model, Phillip 1140 using $\mathrm{Cu}$ as the target metal (Kalpha), Voltage: 40.0(kV), Current: 30.0(Ma), Divergence and Scatter Slit :1.00000(deg.), Receiving Slit: $0.30000(\mathrm{~mm})$, Drive axis: theta-2theta, Scan range: 2.0000-60.0000(deg.), Scan mode: continous scan, Scan speed: $8.0000($ deg./min), Sampling pitch: 0.0200(deg.) and Preset time: 0.15(sec.) was employed. The monochromatic x-rays are projected onto a crystalline material at an angle $(\Theta)$, diffraction occurs when the distance travelled by the rays reflected from successive planes differs by an integer (n) of wavelengths. By varying the angle, the Bragg's law conditions are satisfied by the different $d$-spacing. Plotting the angular positions and intensities of the resultant diffracted peaks produces a characteristic pattern. Where different phases are present, the diffraction trace represents the sum of the individual patterns. The relative abundance of the minerals present can be calculated using the Peak area method of Carrol, (1970).

\section{RESULTS AND DISCUSSION}

Table 1 shows the result from the chemical analysis of the rock samples. The concentration of $\mathrm{SiO}_{2}$ is highest in sample four with a value of $66.40 \%$ which indicates that the magma that gave rise to the rock is probably 
felsic. The $\mathrm{SiO}_{2}$ concentration of sample two and four is $55.25 \%$ and $64.84 \%$, respectively, indicating that the rocks are probably of intermediate magma. However, sample one and three have $\mathrm{SiO}_{2}$ values of $51.41 \%$ and $53.41 \%$ respectively which denotes it to be mafic. The weight percent (wt\%) of $\mathrm{Al}_{2} \mathrm{O}_{3}$ for sample one, two, three, four and five as analyzed are $36.25 \%, 33.30 \%, 32.00 \%, 23.20 \%$ and $21.37 \%$, respectively. The weight percent divided by the molar mass gave the molar proportion of $\mathrm{Al}_{2} \mathrm{O}_{3}$ with values of $0.347,0.320,0.308,0.223,0.205$ for sample one, two, three, four and five, respectively. The individual weight percent of $\mathrm{CaO}+\mathrm{Na}_{2} \mathrm{O}+\mathrm{K}_{2} \mathrm{O}$ divided by their individual molar masses gave the molar proportion of $\mathrm{CaO}+\mathrm{Na}_{2} \mathrm{O}+\mathrm{K}_{2} \mathrm{O}$ after the summation of their individual values $\left(\mathrm{CaO}+\mathrm{Na}_{2} \mathrm{O}+\mathrm{K}_{2} \mathrm{O}\right)$ of 0.0081 , $0.0142,0.0102,0.0101,0.0146$ for sample one to five, respectively. The molar proportions of $\mathrm{Al}_{2} \mathrm{O}_{3}$ was subsequently divided by the molar proportion of $\mathrm{CaO}+\mathrm{Na}_{2} \mathrm{O}+\mathrm{K}_{2} \mathrm{O}$ giving values of $43.10,22.54,30.06$, $22.10,14.07$ for sample one to five, respectively (Table 2). According to Shand's classification of 1927 , for a rock to be considered as peraluminous, the weight percent of $\mathrm{Al}_{2} \mathrm{O}_{3}$ should be greater than the molar proportions of $\mathrm{Al}_{2} \mathrm{O}_{3}$ divided by $\mathrm{CaO}+\mathrm{Na}_{2} \mathrm{O}+$ $\mathrm{K}_{2} \mathrm{O}$ i.e $\left(\mathrm{Al}_{2} \mathrm{O}_{3} / \mathrm{CaO}+\mathrm{Na}_{2} \mathrm{O}+\mathrm{K}_{2} \mathrm{O}\right)$. Sample two, three, four, and five satisfies these condition and they are therefore peraluminous. However, for sample one the weight percent of $\mathrm{Al}_{2} \mathrm{O}_{3}$ is less than the molar proportions of $\mathrm{Al}_{2} \mathrm{O}_{3}$ divided by that of $\mathrm{CaO}+\mathrm{Na}_{2} \mathrm{O}+\mathrm{K}_{2} \mathrm{O}\left(\mathrm{Al}_{2} \mathrm{O}_{3} / \mathrm{CaO}+\mathrm{Na}_{2} \mathrm{O}+\mathrm{K}_{2} \mathrm{O}\right)$, hence, it is therefore considered to be peralkaline. The table below carefully illustrates the sample groupings into the peralkaline or peraluminous using Shand's classification (Table 2).

Table 1: Chemical composition of some major and trace oxides (wt \%)

\begin{tabular}{lllllll}
\hline Sample No. & Elemental oxides & $\mathbf{1}$ & $\mathbf{2}$ & $\mathbf{3}$ & $\mathbf{4}$ & $\mathbf{5}$ \\
\hline 1 & $\mathrm{SiO}_{2}$ & 51.41 & 55.25 & 53.41 & 66.40 & 64.84 \\
2 & $\mathrm{Al}_{2} \mathrm{O}_{3}$ & 36.25 & 33.30 & 32.00 & 23.20 & 21.37 \\
3 & $\mathrm{Fe}_{2} \mathrm{O}_{3}$ & 7.20 & 6.34 & 8.63 & 5.89 & 8.02 \\
4 & $\mathrm{MgO}$ & 1.22 & 1.97 & 1.73 & 0.98 & 2.11 \\
5 & $\mathrm{~K}_{2} \mathrm{O}$ & 0.02 & 0.87 & 0.56 & 0.33 & 0.90 \\
6 & $\mathrm{Ti}_{2} \mathrm{O}$ & 2.73 & 1.45 & 3.01 & 1.76 & 2.08 \\
7 & $\mathrm{P}_{2} \mathrm{O}_{5}$ & 0.05 & 0.08 & 0.03 & 0.10 & 0.08 \\
8 & $\mathrm{SO}_{2}$ & 0.06 & 0.03 & $\mathrm{ND}$ & $\mathrm{ND}$ & 0.01 \\
9 & $\mathrm{~V}_{2} \mathrm{O}_{5}$ & 0.15 & 0.13 & 0.09 & 0.12 & 0.13 \\
10 & $\mathrm{CaO}_{13}$ & 0.38 & 0.26 & 0.17 & 0.30 & 0.23 \\
11 & $\mathrm{MnO}$ & 0.01 & 0.01 & $\mathrm{ND}$ & 0.01 & $\mathrm{ND}$ \\
12 & $\mathrm{NiO}_{13}$ & 0.07 & 0.04 & 0.02 & 0.03 & 0.02 \\
14 & $\mathrm{Cr}_{2} \mathrm{O}_{3}$ & 0.02 & 0.01 & 0.04 & 0.04 & 0.03 \\
15 & $\mathrm{Na}_{2} \mathrm{O}$ & 0.06 & 0.04 & 0.08 & 0.08 & 0.06 \\
16 & $\mathrm{MO}$ & 0.05 & 0.07 & 0.03 & 0.05 & 0.03 \\
17 & $\mathrm{Ga}_{2} \mathrm{O}_{3}$ & 0.01 & $\mathrm{ND}$ & $\mathrm{ND}$ & 0.02 & 0.01 \\
18 & $\mathrm{Sc}_{2} \mathrm{O}_{3}$ & 0.01 & $\mathrm{ND}$ & 0.01 & $\mathrm{ND}$ & $\mathrm{ND}$ \\
19 & $\mathrm{Eu}_{2} \mathrm{O}_{3}$ & 0.02 & 0.06 & $\mathrm{ND}$ & 0.01 & $\mathrm{ND}$ \\
\hline & $\mathrm{CuO}$ & 0.04 & 0.03 & 0.01 & $\mathrm{ND}$ & 0.01 \\
\hline
\end{tabular}

Table 2: Alumina saturation of samples from Ojirami-Ogbo

\begin{tabular}{|c|c|c|c|c|c|}
\hline $\begin{array}{l}\text { Sample } \\
\text { No. }\end{array}$ & $\begin{array}{l}\text { Weight } \\
\% \\
\left(\mathrm{Al}_{2} \mathrm{O}_{3}\right)\end{array}$ & $\begin{array}{l}\text { Weight\% } \\
/ \text { Molar } \\
\operatorname{Mass}\left(\mathrm{Al}_{2} \mathrm{O}_{3}\right)\end{array}$ & $\begin{array}{l}\text { Weight\%/Molar } \\
\text { Mass } \\
\left(\mathrm{CaO}+\mathrm{Na}_{2} \mathrm{O}+\mathrm{K}_{2} \mathrm{O}\right)\end{array}$ & $\begin{array}{l}\mathrm{Al}_{2} \mathrm{O}_{3} / \\
\mathrm{CaO}+\mathrm{Na}_{2} \mathrm{O}+\mathrm{K}_{2} \mathrm{O}\end{array}$ & $\begin{array}{l}\text { Alumina } \\
\text { Saturation }\end{array}$ \\
\hline Sample 1 & 36.25 & 0.347 & 0.0081 & 43.10 & Metaluminous \\
\hline Sample 2 & 33.30 & 0.320 & 0.0142 & 22.54 & Peraluminous \\
\hline Sample 3 & 32.00 & 0.308 & 0.0102 & 30.06 & Peraluminous \\
\hline Sample 4 & 23.20 & 0.223 & 0.0101 & 22.10 & Peraluminous \\
\hline Sample 5 & 21.37 & 0.205 & 0.0146 & 14.07 & Peraluminous \\
\hline
\end{tabular}

Figure 3 shows the concentration of $\mathrm{SiO}_{2}$ which ranges from $51.41 \%-66.40 \%$ and $\mathrm{Al}_{2} \mathrm{O}_{3}$ from $21.37 \%-36.25 \%$ with the former having generally a positive trend (increase) as observed through all the samples, however, there is a slight drop in sample 3 . The high $\mathrm{SiO}_{2}$ content in sample 4 and 5 may be due to the less effects of assimilation of the pre-existing rocks (Quartz Mica Schist and Psammite Pelite Sequence) during the Pan African Event, being that sample 4 and 5 are further away from the contacts. The silica content may also be due to the composition of the melt (Rahaman, 1988; Odeyemi, 1988). There is a negative trend (decrease) for $\mathrm{Al}_{2} \mathrm{O}_{3}$ concentration from sample 1 to 5 . The low $\mathrm{Al}_{2} \mathrm{O}_{3}$ content as one moves from sample 1 to sample 5 may be due to the low concentration of alumina-rich minerals such as garnets, biotite. This is observed as one move away from the contact towards the igneous body (Rahaman, 1988; Odeyemi, 1988). 


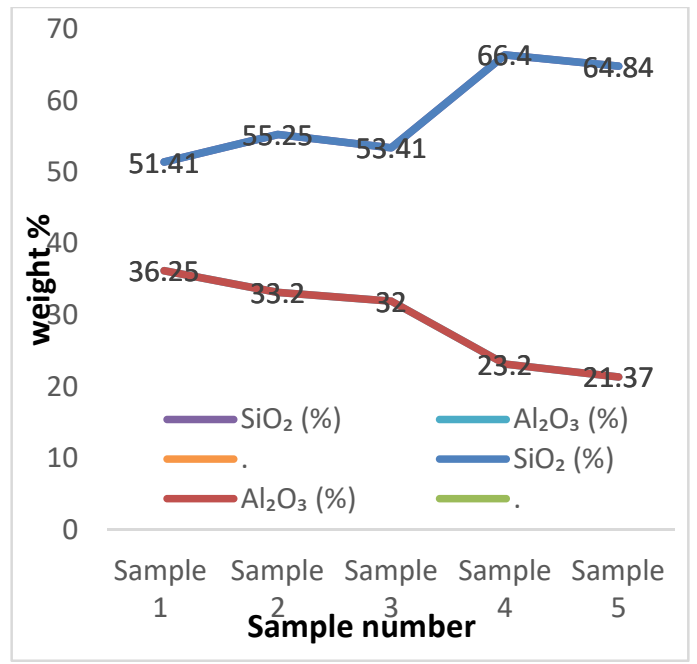

Fig 3: The $\mathrm{SiO}_{2}$ and $\mathrm{Al}_{2} \mathrm{O}_{3}$ in weight $\%$ of the samples

Figure 4 shows the relationship between $\mathrm{Fe}_{2} \mathrm{O}_{3}, \mathrm{MgO}$ and $\mathrm{CaO}$. The aforementioned oxides range from 5.89$8.63 \%, 0.98-2.11 \%$ and $0.17-0.38 \%$, respectively. The $\mathrm{CaO}$ and $\mathrm{MgO}$ content generally have a positive trend which is indicative of the little contributions from minerals like albite and the magnesian minerals such as biotite and hornblende. The $\mathrm{Fe}_{2} \mathrm{O}_{3}$ content generally has a positive trend with much of the iron occurring as hematite.

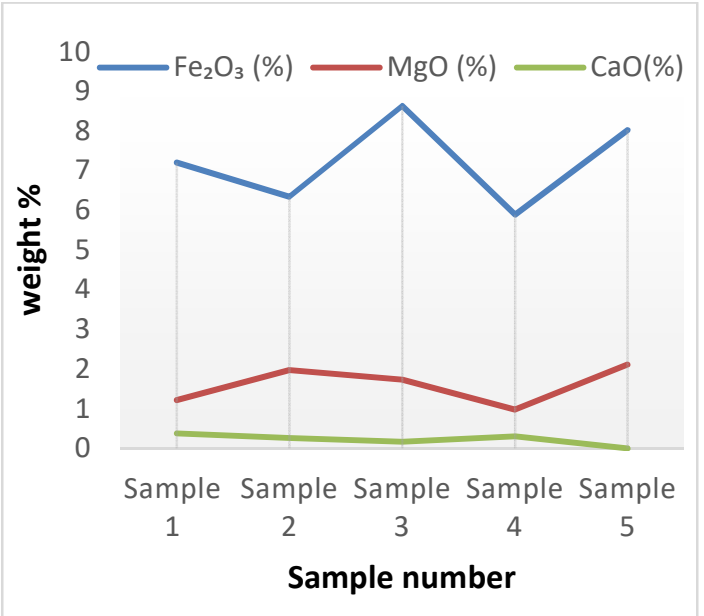

Fig 4: $\mathrm{The} \mathrm{Fe}_{2} \mathrm{O}_{3}, \mathrm{MgO}$ and $\mathrm{CaO}$ in weight $\%$ of the samples

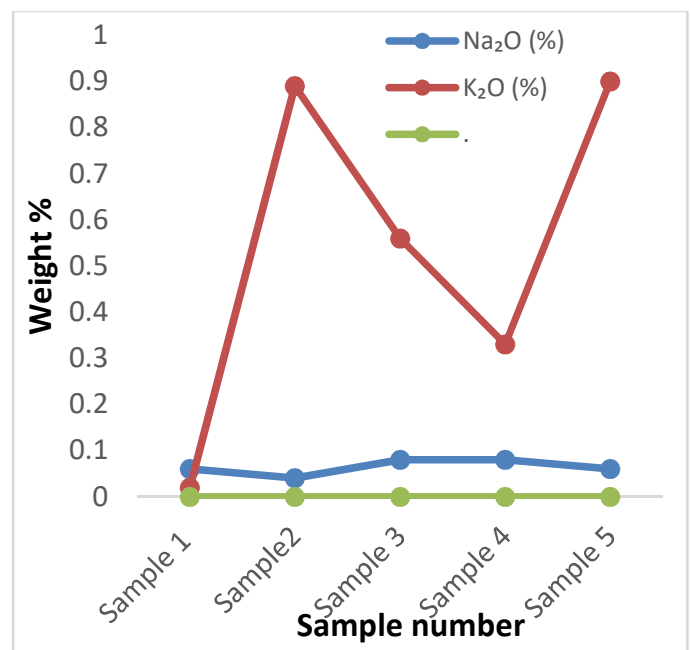

Fig 5: $\mathrm{Na}_{2} \mathrm{O}$ and $\mathrm{K}_{2} \mathrm{O}$ in weight $\%$ of the samples

Figure 5 shows the relationship between $\mathrm{K}_{2} \mathrm{O}(0.02$ $0.90 \%)$ and $\mathrm{Na}_{2} \mathrm{O}(0.03-0.08 \%)$ and reveals a weak positive trend for both oxides which agrees with the school of thought that high $\mathrm{SiO}_{2}, \mathrm{~K}_{2} \mathrm{O}$ and $\mathrm{Na}_{2} \mathrm{O}$ is common with felsic melts (Ukaegbu and Okonny, 1998). The XrD analysis revealed that the rocks are majorly composed of quartz, alkali and plagioclase feldspars. The relative abundance of the aforementioned minerals is presented on table 3. The alkali feldspars comprise albite and sanidine while the plagioclase feldspars include mesotypic albites (Oligoclase-Labradonite). The modal composition for the minerals was recalculated to $100 \%$ and used to plot the rock type on the QAP diagram (Figure 6). Sample one has $60 \%$ quartz, $20 \%$ alkali and plagioclase feldspars, respectively, sample two has $64.3 \%$ quartz, 25.7 and $10 \%$ alkali and plagioclase feldspars, sample 3 has $40 \%$ quartz, $50 \%$ and $10 \%$ alkali and plagioclase feldspars, sample four has $50 \%$ quartz and $30 \%$ and $20 \%$ alkali and plagioclase feldspars and sample five has $34.3 \%$ quartz, $35.7 \%$ and $30 \%$ alkali and plagioclase feldspars. In the QAP diagram, three of the samples (sample 1, 3, and 4) plot within the granite field, while sample 2 and five 5 plot within the quartzrich granitoid and granodiorite field, respectively

Table 3. The relative abundance of felsic minerals in samples.

\begin{tabular}{lllll}
\hline Sample & Q & A & P & RESULT \\
\hline No & Quartz & Alkali feldspar & Plagioclase & \\
$\mathbf{1}$ & 60 & 20 & 20 & Granite \\
$\mathbf{2}$ & 64.3 & 25.7 & 10 & Quartz-rich Granitoid \\
$\mathbf{3}$ & 40 & 50 & 10 & Granite \\
$\mathbf{4}$ & 50 & 30 & 20 & Granite \\
$\mathbf{5}$ & 34.3 & 35.7 & 30 & Granodiorite \\
\hline
\end{tabular}




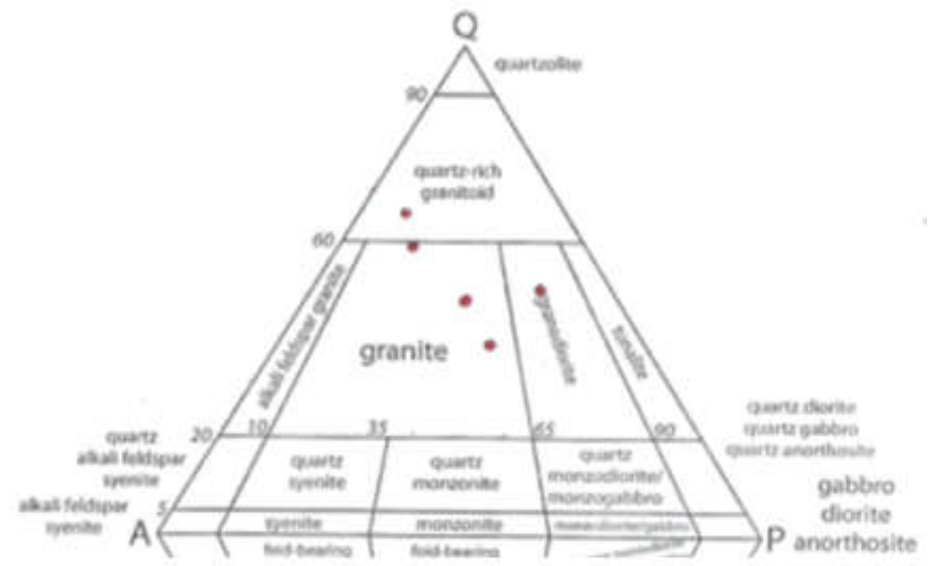

Fig. 6: The QAP diagram showing sample plot

Conclusion: Granitoids are varieties of coarse grained plutonic rocks which are composed mainly of quartz, alkali and plagioclase feldspar. The concentration of $\mathrm{SiO}_{2}$ in the rocks indicates the probable acidic to basic nature of the melt that gave rise to the rocks. The rocks are all peraluminous, which indicates their high $\mathrm{Al}_{2} \mathrm{O}_{3}$ content except one which is metaluminous. The rocks all fall within the granitoid region, having greater than $20 \%$ quartz, alkaline and plagioclase feldspars, except one which falls within the quartz-rich granitoids because of its high quartz content.

\section{REFERENCES}

Ajibade, AC; Fitches, WR. (1988): The Nigerian Precambrian and the Pan-African Orogeny, Precambrian Geology of Nigeria, pp. 45-53.

Carrol, RE. (1970). Clay Minerals: A guide to their X-ray identification. Geol. Soc. Am. Spec. 126, 80

McCurry, P (1976). The Geology of the Precambrian to Lower Palaeozoic rocks of Northern Nigeria, a review, in Geology of Nigeria, pp 15-39, Elizabelthan pub. Co. Lagos

McCurry, P; Wright, JB (1971). On place and time in orogenic granite plutonism. Geol. Soc. Amer. Bull., 82, 1713-1476

Odeyemi, IB (1988). Lithostratigraphy and structural relationships of the Upper Precambrian metasediments in Igarra area, SW, Nigeria. In: Oluyide et al., (eds.) Precambrian Geology of Nigeria
Odeyemi, IB (1976). Preliminary report on the field relationships of basement complex around Igarra, Midwest Nigeria, in Geology of Nigeria, edited by C. A. Kogbe, pp. 59-63, Elizabethan publ. Co. Lagos.

Oyawoye, MO (1972). The basement complex of Nigeria; In African Geology, Ibadan 1970

Eds. Dessauvagie and Whiteman, Geology Department, University of Ibadan, Nigeria, pp.67-99

Rahaman, MA (1976). A review of the basement geology of SW Nigeria In: Geology of Nigeria (Edited by Kogbe, C.A.), pp 41-58 Elizabethan, Lagos.

Rahaman, MA (1988). Recent advances in study of the Basement Complex of Nigeria. Precambrian geology of Nigeria. In: Precambrian Geology of Nigeria (Edited by Nehikhare, J. I.), 12-41

Shand, SJ (1927). Eruptive rocks, their Genesis, Composition, Classification and their reaction to ore deposits with a Chapter on Meteorites, Murby, London. Nature 120,872

Streckeisen, AL (1976). To each Plutonic Rock, its proper name. Earth Sci. Rev., 12, 1-34

Ukaegbu, VU; Okonny, IP (1998). Introduction to Igneous and Metamorphic Petrology. Josany PHC, Port Harcourt, Nigeria. Pp. 12-120 